\title{
Study of the stratification process at the reservoir of the hydroelectric power plant Gov. Pedro Viriato Parigot de Souza (Capivari-Cachoeira), Paraná, Brazil
}

\author{
Sarah Meier Lopes ${ }^{1+}$, Nicole Machuca Brassac de Arruda ${ }^{2}{ }^{\oplus}$, Thomaz Aurélio Pagioro ${ }^{1 \oplus}$ \\ ${ }^{1}$ Technological Federal University of Paraná, 3165 Sete de Setembro Av, Curitiba, Paraná, Brazil \\ 2 Institute of Technology for Development, Lactec, 8813 BR 116 Hwy, km 98, Curitiba, Paraná, Brazil \\ + Corresponding author: Sarah Meier Lopes, e-mail address: sah.mlopes@gmail.com
}

\section{ARTICLE INFO}

Article history:

Received: December 7, 2017

Accepted: June 10, 2018

Published: August 23, 2018
Keywords:

1. densimetric Froude number

2. residence time

3. hydrology

ABSTRACT: The study of the stratification processes in reservoirs is important because they happen along with several physical and chemical changes in the water, as in the distribution of dissolved gases and nutrients. The aim of this work was to study the stratification process of the Capivari-Cachoeira Hydroelectric Power Plant reservoir, based on the data of the vertical profiles of dissolved oxygen and temperature, as well as the comparison of them with the calculation of Densimetric Froude Number, and reservoir residence time. The data used are part of the selfmonitoring program carried out by COPEL. These data were collected quarterly between 2005 and 2016. The hydraulic and operational data

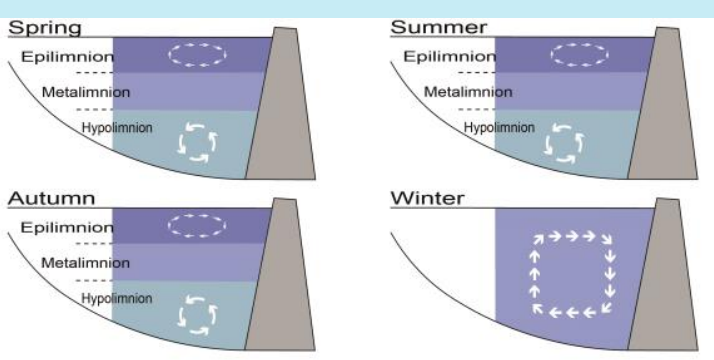
from the reservoir were used to calculations. Warm monomictic circulation pattern of the Capivari-Cachoeira HPP Reservoir According to the measurements of dissolved oxygen and temperature, the reservoir was considered to be stratified during almost all the year, with a trend of circulation in the colder months, this behavior characterizes lakes with warm monomictic circulation pattern. Therefore, the result of Densimetric Froude Number corresponded correctly with the observed. Regarding the residence time, this was not consistent with the results obtained from the models. The use of different methodologies in evaluating circulation in reservoirs should be used to make the best management decision.

\section{Introduction}

The differences in temperature in lakes and reservoirs generate layers with different densities, forming a physical barrier that prevents circulation. This situation happens especially when the wind energy is not sufficient to mix the layers, therefore the heat is not evenly distributed through the water column, generating long lasting thermal stratification $^{1-3}$.

Epilimnion is the upper, hotter and less dense layer of water, being very homogeneous by the action of wind and thermal heating that occurs during the day, and thermal cooling at night. Hypolimnion is the bottommost, dense, lower- water layer. The layer of water between epilimnion and hypolimnion is the metalimnion. The thermocline is the layer in the metalimnion region that exhibits a temperature drop gradient of at least $1{ }^{\circ} \mathrm{C}^{2-4}$. The layers that are formed are often physically, chemically and biologically differentiated from each other ${ }^{1-6}$.

In most water bodies that have thermal stratification, there is also chemical stratification, in which oxygen and other dissolved compounds may, in general, have an inhomogeneous distribution in the water column ${ }^{1-3}$. Thermal stratification is considered the most important limnological characteristic in deep lakes and reservoirs, since it affects from the heterogeneity 
and distribution of the chemical elements in the water column until the composition of its biological community ${ }^{1,2,4-6}$.

The study of the stratification processes in reservoirs is important because they occur together with several physical and chemical changes in the water body, such as, distribution of dissolved gases and nutrients in the water, accumulation of substances and chemical elements in the hypolimnion, as reducing substances and the consequent deoxygenation of hypolimnion. These changes may favor eutrophication events, due to the accumulation of internal charge $e^{2-5}$.

The study of Governador Pedro Viriato Parigot de Souza hydroelectric power plant (HPP) reservoir, located in Bocaiuva do Sul, in the state of Paraná, Brazil, is very relevant due to the fact that the reservoir is part of the future planning of sources for water supply in the metropolitan region of Curitiba, being important the knowledge of its dynamics of circulation, that directly reflects in its characteristics and quality of its waters ${ }^{7}$.

The Densimetric Froude Number is an indicator, calculated by an equation that tries to predict the possibility of a reservoir being stratified. The Densimetric Froude number equation is based on the comparison between the force of inertia of the flow through the reservoir and the gravitational force that tends to maintain the density stability as established by ${ }^{8,9}$.

This equation was used to evaluate the tendency of stratification in 30 reservoirs of small and medium-sized hydroelectric plants planned for the Taquari-Antas river basin ${ }^{5}$. The stratification processes were also studied in four reservoirs of the Iguaçu Basin by the evaluation of dissolved oxygen and temperature profiles, as well as the calculation of the Densimetric Froude number and the residence time ${ }^{7}$. This model was also used to determine the possibility of stratification and or circulation in the Santo Hipólito reservoir, in Minas Gerais ${ }^{10}$. The behavior of physical, chemical and biological stratification in the Rio das Pedras reservoir, located in São Bernardo do Campo, São Paulo, was studied ${ }^{4}$.

Other studies were also carried out in Brazil. The thermal behavior of the São Pedro reservoir used for water supply, located in the city of Juiz de Fora, Minas Gerais, was studied through mathematical modelling to evaluate the surface water temperature, based on meteorological and hydrological data ${ }^{11}$. The stratification of the water column of the Poxim reservoir was also studied from the vertical profiles of temperature, conductivity, total dissolved solids, dissolved oxygen and $\mathrm{pH}^{12}$. A reservoir located in the Brazilian Pantanal was studied to understand the seasonal variations in the vertical structure of the water column and to quantify the importance of physical forces, radiation, wind and hydraulic retention time in the mixing processes in the water column ${ }^{6}$.

In this concept, the effect of thermal stratification on the water quality of the Tahtali reservoir, Turkey ${ }^{13}$, was also evaluated. Thermal stratification conditions of Heihe Reservoir, Shanxi Province, 2008-2010 ${ }^{14}$ were studied as well. In addition, studies that evaluate the influence of stratification on physical and chemical parameters in reservoirs, showed its influence on the microbial community. These researches were all performed in Chinese reservoirs ${ }^{15,16}$.

Chinese reservoirs Guanjingkou and Fengdou, that are still under construction, were previously studied using numerical methods with Delft3d software package in order to simulate the water temperature profile in the reservoirs, the water temperature released by the future spillways and the temperature effect of the water released ${ }^{17}$. The stratification of small temperate lakes of the Cárpados basin, in Turkey, and its biological consequences were also studied ${ }^{18}$. Three lakes in the United States of America were studied in order to investigate the response of water temperature and stratification in different morphometry (water depth and surface area) due to changes in temperature and wind speed ${ }^{3}$.

The objective of this study was to evaluate the Governador Pedro Viriato Parigot de Souza hydroelectric power plant reservoir, known as Capivari-Cachoeira, based on the stratification processes, from the data collected in the field from vertical profiles of dissolved oxygen and temperature, and comparing these results with the Densimetric Froude number and the reservoir's calculated water residence time.

\section{Materials and methods}

\subsection{Study area and analyzed variables}

The study area was the Capivari-Cachoeira HPP reservoir, in which the Capivari River was barred for the construction of the reservoir. The reservoir is located in the Ribeira basin, located in the cities of Bocaiuva do Sul, and Campina Grande do Sul, 
in the state of Paraná, shown in Figure 1. From the reservoir, waters are transposed to the Litorânea basin, flowing into the Cachoeira River, through an underground adduction tunnel ${ }^{19}$. The analyzed data were collected quarterly between 2005 and 2016, at a sampling station located in the reservoir near the dam and the bottom dump, at the geographic coordinates $25^{\circ} 08^{\prime} 25.7$ "S $48^{\circ} 52^{\prime} 19.0^{\prime \prime} \mathrm{W}$. In order to carry out a seasonal investigation, the samples were collected in the spring (September, October and November), summer (December, January, February and March), autumn (April, May) and winter (June, July and August). These data belong to the program of self-monitoring of water quality of hydroelectric reservoirs, carried out by Paranaense Energy Company (COPEL) and developed by the Institute of Technology for Development (LACTEC Institutes).

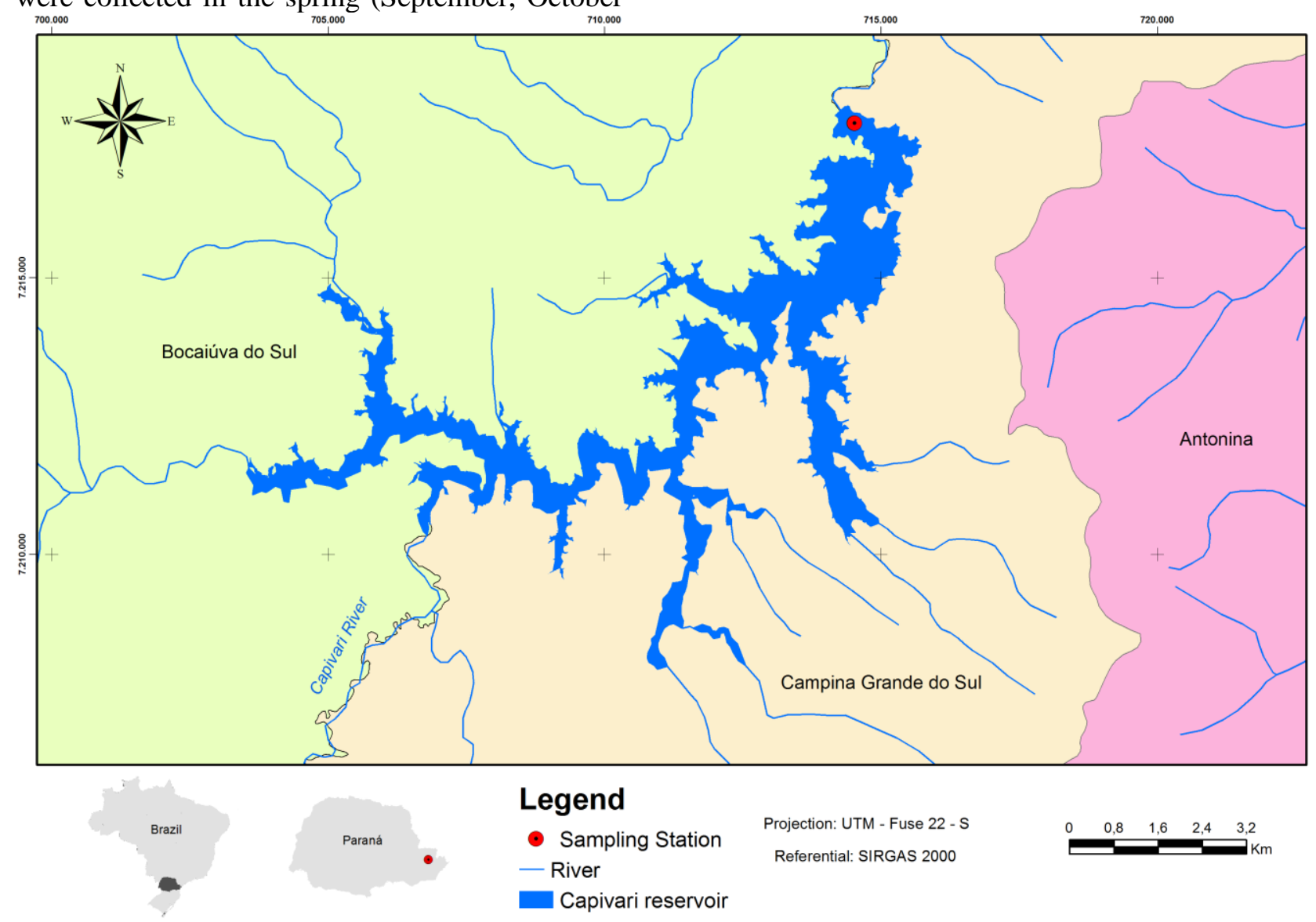

Figure 1. Capivari-Cachoeira HPP reservoir's location.

Source: Adapted from ref. 23.

Since 2005, COPEL has been systematically monitoring the water quality of its hydroelectric power plants in Paraná, aiming to meet the environmental licensing conditioners. The LACTEC Institute manages this monitoring activity, conducting and managing laboratorial analysis and maintaining the water quality database of reservoirs and related rivers ${ }^{19,20}$.

The studied variables were those related to the thermal structure and the distribution of dissolved oxygen in the water column. For this analysis vertical profiles were created, meter by meter, using data of temperature and dissolved oxygen.
Due to the accesses to the sampling station, changes in the coordinates of the collection site may have occurred during the monitoring. The measurements of dissolved oxygen and water temperature were performed in the field by a YSI PRO ODO multiparameter probe, which measures dissolved oxygen from $0-50 \mathrm{mg} \mathrm{L}^{-1}$ (from 0 to $\left.20 \mathrm{mg} \mathrm{L}^{-1} \pm 0.1 \mathrm{mg} \mathrm{L}^{-1}\right)$, and temperature from $5{ }^{\circ} \mathrm{C}$ to $70{ }^{\circ} \mathrm{C}\left( \pm 0.2{ }^{\circ} \mathrm{C}\right)^{21}$. Through these results, the oxygen and temperature profiles were determined using the Microsoft Excel software ${ }^{22}$, for the analysis of thermal and chemical stratification in the studied reservoir. 
Table 1 presents the hydraulic and operational data of the analyzed reservoir, from the power plant's original project ${ }^{23}$. These data were used to perform the calculation of the residence time and the Densimetric Froude number.

Table 1. Capivari-Cachoeira reservoir's hydraulic and operational data.

\begin{tabular}{c|c}
\hline Characteristic & $\begin{array}{c}\text { Capivari- } \\
\text { Cachoeira HPP } \\
\text { Reservoir }\end{array}$ \\
\hline $\begin{array}{c}\text { Altitud next to the } \\
\text { damn }(\mathrm{m})\end{array}$ & 837.50 \\
\hline $\begin{array}{c}\text { Medium long term } \\
\text { dischard }\left(\mathrm{m}^{3} \mathrm{~s}^{-1}\right)\end{array}$ & 19.40 \\
\hline Volume $\left(\mathrm{hm}^{3}\right)$ & 186.00 \\
\hline Flooded area $\left(\mathrm{km}^{2}\right)$ & 13.20 \\
\hline Lenght $\left(\mathrm{km}^{2}\right)$ & 21.25 \\
\hline Medium Deepth $(\mathrm{m})$ & 13.60 \\
\hline Maximum Deepth $(\mathrm{m})$ & 45.00 \\
\hline
\end{tabular}

Source: [23]

\subsection{Water Residence Time (RT)}

The evaluation of the stratification tendency of a reservoir can be calculated using several indices and parameters. The residence time is one of the simplest, which classifies the reservoirs based on the mean water holding time, the average time a reservoir takes to renew its entire volume ${ }^{5,7,9}$. It is expressed by Equation 1:

$\mathrm{RT}=11.57 \frac{\mathrm{V}}{\mathrm{Q}}$

Where RT: residence time in days; V: reservoir volume in cubic hectometers $\left(10^{6} \mathrm{~m}^{3}\right)$; Q: average long period flow in cubic meters per second.

The classification adopted for the CapivariCachoeira reservoir was made considering the volume ratio of the reservoir / average flow affluent to it and the residence time ${ }^{8,9}$. The classification is the following: a) Reservoirs with RT > 1 year: small seasonal variations are observed in the water volume and the outflow is withdrawn from the surface; b) Four months < RT < 1 year: present stratification and great variation in water volume; and c) Reservoirs with RT $<4$ months: stratification is difficult to establish, and longitudinal temperature variation may occur. However, this equation should be used only as an indicator of general conditions of the reservoir, because, for example, there are deep-water reservoirs with a short residence time ${ }^{9}$.

\subsection{Densimetric Froude Number $(F d)$ calculation method}

The Densimetric Froude number (Fd) is considered the best parameter to evaluate the thermal stratification trend of a reservoir because it brings together the main characteristics of stratification and morphometry. Its expression relates the forces of inertia responsible for mixing the reservoir water mass and the gravitational force, a consequence of the stratification (Equation 2) ${ }^{5-9}$ :

$$
\mathrm{Fd}=0.322 \frac{\mathrm{L}^{*} \mathrm{Q}}{\mathrm{H}^{*} \mathrm{~V}}
$$

Where Fd: Densimetric Froude Number; L: reservoir length $(\mathrm{km})$; Q: flow $\left(\mathrm{m}^{3} \mathrm{~s}^{-1}\right) ; \mathrm{H}$ : mean depth (m); V: volume $\left(10^{6} \mathrm{~m}^{3}\right)$.

In this method, the tendency of stratification in a reservoir is classified as following: A) strong: $\mathrm{Fd}$ less than or equal to $0.1 ; b)$ medium: in which stratification occurs, but horizontal temperature gradients may also occur ( $\mathrm{Fd}$ greater than 0.1 and less than 0.3); and c) weak: Fd greater than or equal to 0.3 and less than 1.0. Fd values greater than 1.0 indicate mixed regime and, therefore, no stratification $^{5-9}$.

\section{Results and discussion}

The results of the calculation of the residence time and the Densimetric Froude number are presented in Table 2 and were compared with the dissolved oxygen and temperature profiles made by the collected data (between 2005 and 2016). In the Figure 2, as an example of the vertical profiles of the monitoring cycle of 2005-2006, is represented the stratification pattern identified in the reservoir.

Table 2. Densimetric Froude number and water residence time results.

\begin{tabular}{l|c|c}
\hline Reservoir & RT (days) & Fd \\
\hline Capivari- & 110.90 & 0.052 \\
Cachoeira & & \\
\hline & Legend: RT: water residence time; Fd: \\
Densimetric Froude number.
\end{tabular}




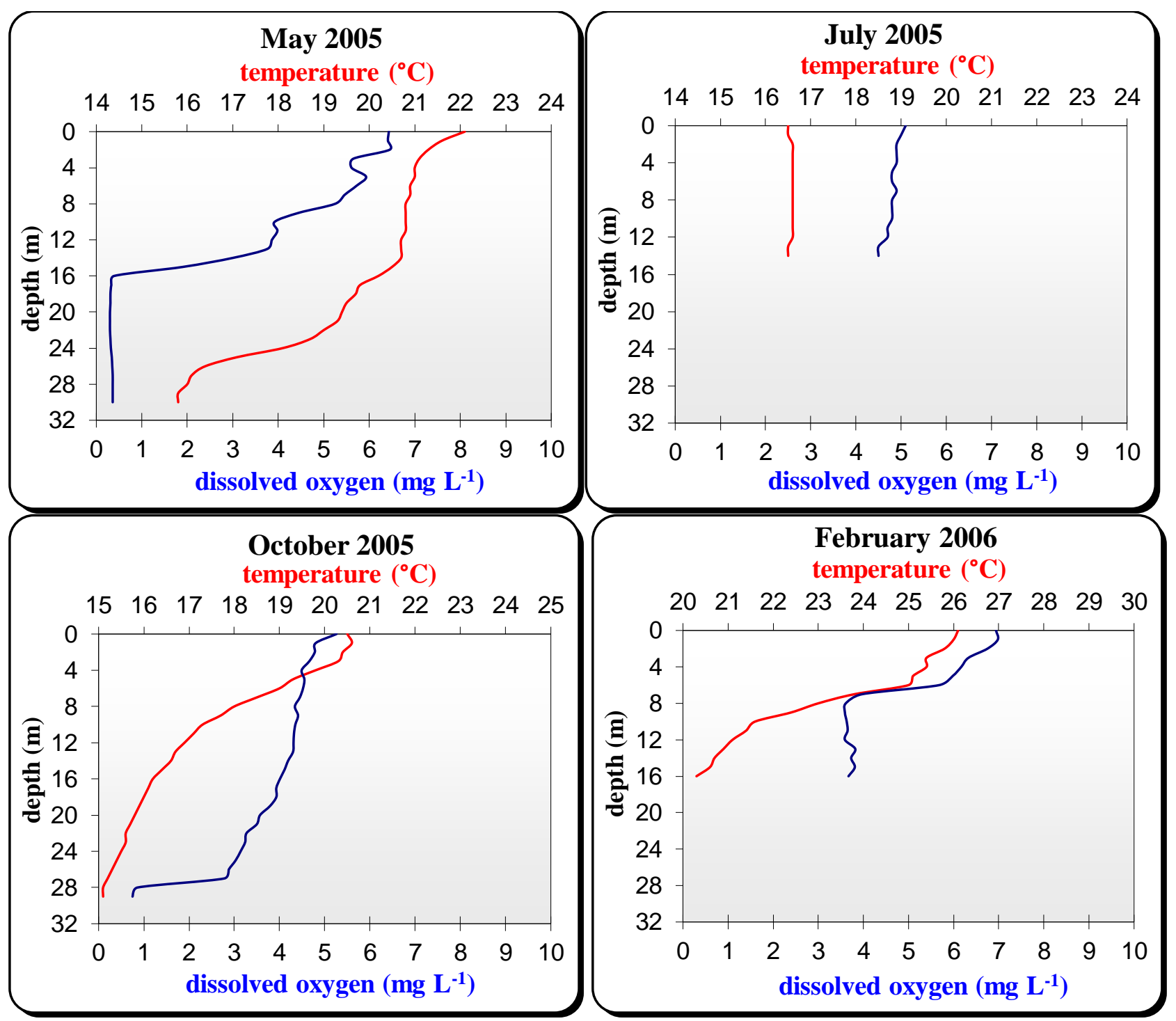

Figure 2. Dissolved oxygen and temperature profiles in Capivari-Cachoeira reservoir, examples from 2005 and 2006 data ${ }^{23}$.

The measurements of dissolved oxygen and temperature reflected the behavior of these variables in the vertical profile of the reservoir of the Capivari-Cachoeira HPP. In the evaluation of the temperature profiles it can be observed that the reservoir was stratified predominantly in the warmer months, with a significant drop in surface temperature towards the bottom. While in the months of lower temperatures, the thermal stratification was absent or not very pronounced, with a tendency to water circulation. The change in density of the water molecule varies as a function of temperature, however, this change is not uniform, and with the increase in water temperature, the differences in water density become higher ${ }^{1}$.
A pattern can be observed, in which thermal stratification occurs in most of the annual cycle and the de-stratification and mixing along the water column, once a year, around the month of July and August. This behavior characterizes lakes with warm monomictic circulation pattern. The stratification process in warm monomictic lakes occurs due to the thermal heating of the surface ${ }^{2}$. The warm monomictic circulation pattern was observed in different reservoirs in the state of Paraná, where circulation occurs once a year, predominantly in winter ${ }^{7,24-25}$.

This stratification pattern was considered a tendency since it occurs in almost every monitored year, as observed in Figure 2. For example, the thermocline was superficial in October'05 and February'06, between 4 meters and 10 meters (m) 
reflecting the depth of mixing of the water column on those months, that is, surface circulation, in the first $4 \mathrm{~m}$. In May'05, the thermocline started at 16 $\mathrm{m}$, and presented a second thermocline in $24 \mathrm{~m}$, approximately, showing circulation of the upper layers and in June'05, no stratification occurred. Similar behavior was also observed in a reservoir in the Pantanal, Brazil. The Ponte de Pedra reservoir presented a long stratification period with complete mixing in winter. The vertical structure showed that during the stratification period, the upper layers of the reservoir are homogeneous and that the physical and chemical composition only changes at greater depths ${ }^{6}$.

Evaluating profiles from the years 2005 to 2016, in warmer months (Summer and Spring) it was recorded temperature drops from $3.5^{\circ} \mathrm{C}$ to $10{ }^{\circ} \mathrm{C}$, and the thermoclines started near the surface with a depth of around 2 meters to 15 meters, reflecting the depth of mixing of the water column in these months. To illustrate these stratification events, in the months of October'06 and January'07, temperature dropped of up to $5{ }^{\circ} \mathrm{C}$ in the first $15 \mathrm{~m}$ of the water column. In October'10, the surface temperature loss to the bottom was approximately $10{ }^{\circ} \mathrm{C}$. In January'11, the difference between surface and bottom temperature was almost $6{ }^{\circ} \mathrm{C}$.

In the summers and springs temperatures usually presented a great difference between the surface temperature and the background temperature. A similar situation was observed in three Paraná reservoirs, being the reservoir of the Jordão, Segredo and Foz do Areia, in which thermal stratifications were more pronounced in the months of higher temperatures ${ }^{7}$.

Corroborating these findings, a paper produced in the Rio das Pedras reservoir showed evidences of thermal stratification mainly due to temperature differences, followed by chemical and biological stratification ${ }^{4}$.

Deep reservoirs generally form thermal stratification due to uneven vertical heat distribution. Thermal stratification can hinder vertical water exchange, causing stratification of water quality ${ }^{7}$.

The evaluation of the vertical profile of dissolved oxygen in the Capivari-Cachoeira reservoir showed that it presents stratification during most of the annual period, following the thermal stratification pattern (Figure 2). Similar behavior was found in the reservoir of the HPP Segredo, HPP Salto Caxias, when its stratifications processes were studied ${ }^{7}$. Also, similarities between the present results and other researches were also verified. In Poxim reservoir, in Sergipe, a decrease of the temperature along the water column was also identified, usually accompanied by a decrease of dissolved oxygen, with more stratification occurring in periods with higher temperatures ${ }^{12}$. The vertical distribution of dissolved oxygen in lakes in the Tisza valley demonstrated a chemical stratification characteristic in summer ${ }^{18}$.

Comparing the results found in other studies, there were also significant differences in the physical and chemical parameters, as well as differences in the microbiological parameters between epilimnion and hypolimnion ${ }^{15}$. Results that indicated that the stratification of the reservoir had great effects on the temperature and oxygen profiles, and both the functional diversity and the composition of the bacterial community strongly reflected the significant vertical stratification were also found in the reservoir studied ${ }^{16}$.

As for the distribution of dissolved oxygen in the Capivari-Cachoeira reservoir: events of hypolimnetic hypoxia, when there are marked deficits of dissolved oxygen in the bottom layer, were recorded in several sampling events. In May'05 and October'05, hypolimnetic hypoxia was observed, with concentrations below $1.0 \mathrm{mg} \mathrm{L}^{-}$ ${ }^{1}$, from $15 \mathrm{~m}$ in the first case and below $25 \mathrm{~m}$ in the second (Figure 2). Also, in October'07 and February'08, oxyline was recorded between $2 \mathrm{~m}$ and $3 \mathrm{~m}$ depth, with hypoxia from $25 \mathrm{~m}$ and also from $12 \mathrm{~m}$, respectively. Hypoxia in the bottom region can stimulate eutrophication processes by internal loading, since it makes phosphorus retention difficult in sediments, making it available for the assimilation of living being $\mathrm{s}^{2-5}$.

Events of anoxia were also observed in the Capivari-Cachoeira reservoir, as in April'07, when oxyline was recorded in $6 \mathrm{~m}$, with a decrease of 5.5 $\mathrm{mg} \mathrm{L}^{-1}$ in the concentration of dissolved oxygen towards the bottom and observation of anoxia from $9 \mathrm{~m}$ deep. In October' 14, anoxia occurred from 10 $m$ depth with dissolved oxygen values below 0.7 $\mathrm{mg} \mathrm{L}^{-1}$ and January' 15 , from $8 \mathrm{~m}$, dissolved oxygen values were observed below $0.3 \mathrm{mg} \mathrm{L}^{-1}$.

During the studied period, in summer the stratification was evident, and the observed concentrations of dissolved oxygen fell well below the standard limit in the thermocline, leading to the development of anoxia ${ }^{13}$.

Lakes of tropical regions have their dissolved oxygen profiles influenced mainly by the morphometry of the lake and by high temperatures, 
once the influence of the winds act in the distribution of dissolved oxygen in the water body. Thus, it is common for these lakes to present a strong oxygen deficiency in the water column, especially in the lower bottom ${ }^{1}$.

The results of the calculation of the residence time, 110.9 days (Table 2), considering the classification of WRE $(1969)^{8,9}$, suggests that the Capivari reservoir has little possibility of stratification, due to the great relation flow rate/volume. Thus, because the Capivari-Cachoeira reservoir has a small residence time ${ }^{9}$, less than 4 months, it is suggested that stratification is difficult to be stablished.

However, according to the result of the Densimetric Froude number, which was equal to 0.052, (Table 2), the Capivari reservoir presents a tendency to strong stratification ${ }^{5-9}$, because for the stratification to be developed, low flow velocities are necessary associated with morphology of the reservoir ${ }^{3}$.

According to the measurements of dissolved oxygen and temperature carried out in the Capivari-Cachoeira HPP reservoir during the studied period, the reservoir was considered to be stratified during most of the year, with a circulation trend in the coldest months, especially in the winter, therefore, the result of the Densimetric Froude number, suggesting tendency to strong stratification, corresponded correctly with the observed. In relation to the residence time, its classification was not consistent with the results obtained in the field and with the calculation of Froude number, because according to the result (110.9 days), and the classification proposed ${ }^{8,9}$, it would be difficult for the reservoir to stratify.

The calculation of residence time does not take into account some important features such as depth, thus allowing a general view of the reservoir. The Densimetric Froude number represents the environment with greater accomplishment, since it considers more factors ${ }^{9}$. Thus, several factors must be taken into account in the studies of the stratification and mixing processes of water columns 9 . For example, it has already been identified that larger surface area lakes have a greater mix do to the wind. And larger lakes tend to have more variability in temperature and stratification than smaller lakes, and this variability increases with higher wind speeds ${ }^{3}$.

In another study, in small temperate lakes of the Carpathian basin, it was concluded that depending on their depth and wind shelter, the lakes could be characterized by various stratification patterns ${ }^{18}$. In the São Pedro reservoir, Juíz de Fora, because it is a small and shallow reservoir, the temperatures are more limited to the flows of the tributaries, characterizing, therefore, a low capacity of this reservoir to regularize its temperatures ${ }^{11}$.

\section{Conclusions}

The thermal and dissolved oxygen stratification pattern observed in the Capivari-Cachoeira HPP reservoir is of a warm monomictic lake, in which stratification occurs almost throughout the year, with a higher intensity in summers and tendency to circulate, de-stratification, in the winter. Hypoxia and even anoxia events have been recurrent in the reservoir, in the hipolimnion, and it is also characteristic of warm monomictic environments within periods of reduced circulation.

The calculated Densimetric Froude number corresponded correctly with the stratification trend observed in the monitoring of the oxygen and temperature profiles for the Capivari-Cachoeira reservoir.

On the other hand, the classification adopted for residence time as indicative of the trend of stratification was not consistent with the values obtained in the profiles of temperature and dissolved oxygen and in the calculation of the Densimetric Froude number. In this sense, the use of different methodologies and approaches in evaluating circulation patterns in reservoirs should, whenever possible, be used to make the best management decision.

\section{Acknowledgments}

The authors would like to thank COPEL (Paranaense Energy Company) for the permission to use the water quality monitoring data used in this study.

The authors also would like to thank $\mathrm{CNPq}$ and CAPES for their financial support and LACTEC and UTFPR for logistical support.

\section{References}

[1] Esteves, F. A., Fundamentos de Limnologia, Rio de Janeiro: Interciência, 3rd ed., 2011, ch9.

[2] Tundisi, J. G., Tundisi, T. M., Limnologia. São Paulo: Oficina de Textos, 1rd ed., 2008, ch4. 
[3] Magee, M. R., Wu, C. H., Response of water temperatures and stratification to changing climate in three lakes with different morphometry, Hydrol. Earth Syst. Sci. 21 (2017) 6253-6274. https://doi.org/10.5194/hess-21-6253-2017.

[4] Padial, P.R., Pompêo, M., Moschini-Carlos, V., Heterogeneidade espacial e temporal da qualidade da água do reservatório Rio das Pedras (Complexo Billings, São Paulo), Revista Ambiente \& Água, 4 (3) (2009) 35-53. https://doi.org/10.4136/ambiágua.101.

[5] Benetti, A. D., Tucci, C. E. M., Uso de indicadores para avaliação de usinas hidrelétricas em bacias hidrográficas com múltiplos aproveitamentos, Revista de gestão de água da América Latina 3 (1) (2006) 73-83.

[6] Cruz, I. F., Pedrollo, O., Bonecker, C. C., Zeilhofer, E., Key factor in vertical mixing processes in a reservoir bordering the Pantanal floodplain, Brazil, Hydrological Sciences Journal $60 \quad$ (9) (2015) 1508-1519. https://doi.org/10.1080/02626667.2014.933224.

[7] Miranda, T. L. G., Brassac, N. M., Prestes, E. C., Muller, I. I., Pereira, S., Estudo dos processos de estratificação em grandes reservatórios da Bacia do Rio Iguaçu. In: Simpósio Brasileiro de Recursos Hídricos 18 (2009), Campo Grande, Anais... Campo Grande - MS: ABRH (2009) 1-12.

[8] WRE, 1969, Mathematical Model for Prediction of Thermal Energy Changes in Inpoundments US EPA 16130.

[9] Tucci, C. E. M., Modelos Hidrológicos. Porto Alegre: ABRH, ed. UFRGS, 1998, ch11.

[10] Von Sperling, E., Estudo sobre influência na qualidade da água decorrente da implantação da barragem de Santo Hipólito, Rio Das Velhas-MG, Belo Horizonte: Comitê da bacia hidrográfica do Rio das Velhas (2009) 1-28.

[11] Souza, F. F. C., Ribeiro, C. B. M., Fragoso Junior, C. R., Otenio, M. H., Modelagem do regime térmico de um reservatório tropical de abastecimento público, Juiz de Fora, MG, Brasil, Rev. Ambient. Água 11 (1) (2016) 60-74. https://doi.org/10.4136/ambi-água.1544.
[12] Neves, A. M., Fonseca, L. C., Macedo, L. C. B., Alves, J. P. H. A., Estratificação da coluna d'água do reservatório do rio Poxim, São Cristóvão - Sergipe. In: Simpósio de Recursos Hidrícos do Nordeste 8 (2016) Aracajú, Anais... AracajúSE:ABRH (2016) 1-9.

[13] Elçi, Ş., Effects of thermal stratification and mixing on reservoir water quality, Limnology, (9) (2008)135-142. https://doi.org/10.1007/s10201008-0240-x.

[14] Lu, J., Li, Z., Seasonal effects of thermal stratification on the water quality of deep reservoirs: A case study of Heihe Reservoir, Xi'an City, J. Lake Science 26 (5) (2014) 698-706. https://doi.org/10.18307/2014.0507.

[15] Yu, Z., Yang, J., Amalfitano, S., Yu, X., Liu, L., Effects of water stratification and mixing on microbial community structure in a subtropical deep reservoir, Scientific Reports 25 (4) (2014) 5821. https://doi.org/10.1038/srep05821.

[16] Xiao, Y., Huang, T., Zhang, H., Effects of Seasonal Thermal Stratification on the Functional Diversity and Composition of the Microbial Community in a Drinking Water Reservoir, Water $7 \quad$ (10) (2015) 5525-5546. https://doi.org/10.3390/w7105525.

[17] Jang, J. Y., Zhou, L. Y., Simulation of water temperature in two reservoirs with Delft3d, International Conference on Water Resource and Environment 2016. Series: Earth and Environmental Science $39 \quad$ (2016) 7. http://iopscience.iop.org/1755-1315/39/1/012073.

[18] Borics, G., Abonyi, A., Várbíró, A., Padisák, J., Krasznai, T. E., Lake stratification in the Carpathian basin and its interesting biological consequences, Inland Waters 5 (2015) 173-186. https://doi.org/10.5268/IW-5.2.702.

[19] Copel. Usina Parigot de Souza. (2016). Available in: <http://www.copel.com/hpcopel/root/nivel2.jsp ?endereco $=\% 2$ Fhpcopel $\% 2$ Froot $\% 2$ Fpagcopel2.n sf\%2F044b34faa7cc1143032570bd0059aa29\%2F 
08013ddc621f4eed03257412005ed73>. Acessed in: 01 ago. 2017.

[20] Arruda, N. M. B., Rizzi, N. E., Miranda, T. L. G., Análise multivariada na avaliação da qualidade de água do reservatório de Foz do Areia, estado do Paraná, Revista Brasileira de Ciências Ambientais 37 (2015) 26-37. https://doi.org/10.5327/Z2176947820159514 .

[21] YSI. ProODO Optical Dissolved Oxygen Instrument. (2018). Available in: $\langle$ https://www.ysi.com/proODO $>$. Acessed in: 28 mar. 2018.

[22] Microsoft. Microsoft Office Excel 2013. [S.I.]: Microsoft Inc, (2013).

[23] Lactec - Instituto de Tecnologia para o Desenvolvimento, Relatório Anual do Automonitoramento da Qualidade das Águas Superficiais do Rio Capivari, na região da Usina Governador Pedro Viriato Parigot De Souza (UHE Capivari-Cachoeira), Curitiba: Lactec (2016) 41.

[24] Ferreira, D. M., Cunha, C., Simulação numérica do comportamento térmico do reservatório do Rio Verde, Eng Sanit Ambient 18 (1) (2013) 83-93. https://doi.org/10.1590/S141341522013000100010

[25] Colombo, G. T., Mannich, M., Estudo da estratificação térmica do reservatório Vossoroca por meio de índices físicos, In: Simpósio Brasileiro de Recursos Hídricos, 22 (2017), Florianópolis, Anais... Florianópolis - SC: ABRH (2017) 1-8. 